\title{
Studies on Preparation and Storage of Aonla Candy Enriched with Different Natural Oil/Extract (Emblica officinails L.) cv. NA-7
}

\author{
Rajesh Kumar* and Sanjay Pathak \\ College of Horticulture and Forestry, Narendra Deva University of Agriculture \& \\ Technology; Kumarganj, Faizabad (U.P), India \\ *Corresponding author
}

Keywords

Aonla candy, Chemical changes during storage, Organoleptic rating, Cost: benefit ratio

Article Info

Accepted: 26 September 2020 Available Online: 10 October 2020
A B S T R A C T

Aonla (Emblica officinalis) is an important crop indigenous to Indian subcontinent which is used in alternative medicine, health foods and herbal products. It is also found to be a rich source of ascorbic acid and other bioactive substances as compared to any other fruits. The current research work was taken to the effect of different natural oil/extract on chemical changes in aonla candy during storage. With a view to develop value added products, from aonla cultivar NA-7, candy was prepared under different treatments. The prepared candy was kept at ambient condition for storage study. The candy remained acceptable upto 180 days at ambient condition. The candy prepared from Ginger extract (10 ml/lit) treatment retained maximum amount of ascorbic acid, and non-reducing sugar and appreciable amount of acidity, reducing sugars, total sugars, and total phenol and observed minimum changes in total soluble solids than rest of the treatments and their increasing trend with advancement of storage period upto 180 days was recorded under ambient condition. On the other hand, candy prepared from Ginger extract (10 $\mathrm{ml} / \mathrm{lit})$ had low browning (0.11 OD) and highest organoleptic (8.00) score and these traits showed increasing and decreasing trend respectively with increasing storage period upto180 days. The candy prepared from Ginger extract $(10 \mathrm{ml} / \mathrm{lit})$ had the maximum benefit: Cost ratio (1.52:1), high sensory evaluation score and high nutritional quality.

\section{Introduction}

Aonla fruit is highly nutritive with a great medicinal use and the richest source of vitamin $\mathrm{C}$ next to Barbados cherry. Its contain gallic acid, elegiac acid and glucose which prevent oxidation of vitamin C. Aonla is also a source of carbohydrates, carotene, thiamine, riboflavin, and minerals like iron, calcium, phosphorus, magnesium and rich source in pectin. Its fruit have excellent therapeutic value which is utilized for treatment of several diseases from ancient times like tuberculosis of lungs, asthma, bronchitis, scurvy, diabetes, anemia, weakness of memory, cancer, tension, influenza, cold, loss and grayness of hair etc. Aonla fruits are highly perishable in nature and consumers are hesitant to eat it in raw form due to astringent test. This problem overcome by processing of aonla fruit in to different products like jam, jelly, RTS, 
squash, nectar, juice, canned fruit, ice cream, toffees, preserve, candies, laddu, barfi, Chayvanprash and Triphala. Among these products osmo-dehyderated product/candy is now gaining much popularity in the market due to its natural appeal of an original fruit, nutritional quality, easy to handling and transport, better self life, low preparation cost and good returns. But aonla candy is astringent in taste and have no flavor therefore, product is not gaining popularity as much have potency.

Attempts are being made to produce products which are not only nutritionally delicious but also acceptable among the consumers. The medicinal, nutritional and organoleptic quality of aonla candy can be improve by addition of different natural oil/extract in the aonla candy like Ginger extract, Mentha, Peppermint, lemon, Tulsi, Khus, Eucalyptus oil and Rose, Kewra, Khus water.

Mentha and Peppermint oil are non toxic have longer shelf life, and is widely used for a flavoring agent in processed food products like chocolates, cosmetics, cough drops, mouth fresheners, confectionary, Chewing Tobacco, Pan Masala, tooth pastes, cosmetics and many other uses as health conditions, including nausea, indigestion, cold symptoms, headaches, muscle, nerve pain, and stomach and bowel conditions such as irritable bowel syndrome.

Lemon and Tulsi oils used for culinary purposes and also add a pleasant taste and aroma to food, since they are a good source of vitamins and aid indigestion. The health benefits of these oils include its ability to treat stress disorders, fever, infections, asthma, insomnia, skin disorders, hair conditions, and stomach problems. Khus-Khus oil/water is used extensively in the perfume industries, including perfumes for the body, room fresheners, and coolers, as well as cosmetics, soaps, oils and as a flavoring agent in beverages, sorbets, and food stuffs. Khus oil is boon for individuals suffering from rheumatism, arthritis, gout, muscular aches, dryness and cracking of skin etc.

Numerous rose water benefits include antibacterial, soothing, healing and antiseptic properties. It is very rich in flavonoids and vitamins, including $\mathrm{A}, \mathrm{C}, \mathrm{D}, \mathrm{E}$ and $\mathrm{B}_{3}$. That is why if taken in the form of a therapeutic tea, which can help to lower the risks of bladder infections and heart disease, relieve digestive problems and nervous tension, relieve eye irritation and dental pains caused by paradontosis, and so on. Rose syrup is made from rose water, with sugar added. It is also used in Indian sweets and other food preparations (particularly gulabjamun).

Kewra water is used to flavor meats, drinks, and desserts in India, specially the northern part and Southeast Asia. Sweets like rasgullas, rasmalai and many more Bengali sweets can be dipped or soaked in kewra water to give it a floral flavor. Kewra are also popular as stimulants to cure headaches related problems healing joint pains and bone and provide general relaxation to body.

Eucalyptus oil has numerous traditional uses as non-ingestive treatment for coughs and colds (Opdyke, 1975), and fragrance in soaps, detergents and perfumes and as a flavoring in food (Furia and Bellanca, 1971). Eucalyptus oil carries the US Food and Drug Authority classification GRAS (Generally Regarded as Safe) and is approved for incorporation into foods such as chewing gum and throat lozenges at low concentrations.

Ginger (ZingiberofficinalisL.) is a valuable cash crop and plays an important role in Indian Ayurvedic medicine as a folk remedy to promote cleaning of the body through perspiration, to clam nausea, and to stimulate 
the appetite. Ginger tea is also used as a carminative and in the symptomatic treatment of colds. Ginger contains gingerola an oleoresin, (combination of volatile oils and resin) that accounts for the characteristic aroma and therapeutic properties. Components of gingerol (Zingibirane, bisabolene, Camphene, geranial, Linalool and Borneol) possess beneficial properties for the treatment poor digestion, heartburn vomiting and preventing motion sickness.

Aonla candy prepared with ginger extract found superior in respect of organoleptic quality followed by mentha, lemon and peppermint oil. These candy were packed in polythene packet for further storage study.

\section{Materials and Methods}

The investigation was conducted at Narendra Deva University of Agriculture \& Technology, Kumarganj, Faizabad (U.P.), India; during the year 2013-14. Aonla fruits of NA-7 cultivar having uniform vigour were taken from the aonla orchard at Main Experimental Station of Department of Fruit Science, College of Horticulture \& Forestry of the University in the month of December.

\section{Evaluation of different natural oil/extract for preparation of aonla Osmo-dehydrated product (candy)}

One kilogram of blemish less mature and uniform in size of fresh fruits were taken for each treatment and washed properly with fresh water. These fruits were blanched in boiling water with 2 per cent Sodium bicarbonate $\left(\mathrm{NaHCO}_{3}\right)$ for five minutes. After boiling the aonla fruits segment were separated by hand and washed three times with the fresh water and following method (Fig. 1) should be adopted for flavored aonla candy preparation

\section{Details of treatment}

Mentha oil/peppermint oil/lemon oil/Tulsi oil/khus oil/eucalyptus oil, were procured from the market and added $1.0 \mathrm{ml} / \mathrm{liter}$ in sugar syrup containing $50 \%$ sugar concentration.

Rose water/khus water/ kewra water were procured from the market and added 15.0 $\mathrm{ml} /$ liter in sugar syrup containing 50\% sugar concentration.

Ginger extract were prepared in the post harvest laboratory. Fresh ginger rhizome was procured from the market and then washing followed by peeling and grating after that extract was prepared by adding equivalent amount of water (1:1 ratio) than squeeze after putting in muslin cloth. These extract were added $15.0 \mathrm{ml} /$ liter in sugar syrup containing $50 \%$ sugar concentration.

Above oils/extract were homogeneity mixed in the slightly hot syrup thereafter, aonla segment were deeped.

\section{Chemical analysis}

Best four candy treatments(ginger extract, mentha, peppermint and lemon oil) was kept for storage study at ambient temperature and chemical changes were determined during storage at monthly intervals. TSS ( ${ }^{0}$ Brix) was determined with hand refractometer. Acidity and browning (OD), ascorbic acid and sugars were determined by the procedures of Ranganna (2010), A.O.A.C. (1970) and Lane and Eynon (1923) respectively. Organoleptic evaluation for assessing sensory attributes of the sample was conducted by a panel of eight judges and sample were rated on the nine point of hedonic rating scale described by Amerine et al., (1965). The total phenols were determined by the method of Swain and Hills (1959). One gram sample was crushed with 
$20 \mathrm{ml}$ of 80 per cent ethyl alcohol thereafter; it was centrifuge at $1000 \mathrm{rpm}$ for 15 minutes. $1.0 \mathrm{ml}$ clear extract, $1.0 \mathrm{ml}$ phenol reagent and $2.0 \mathrm{ml}$ sodium bicarbonate 20 per cent were mixed together and shaken well then final volume was maintained up to $50 \mathrm{ml}$ with distilled water. It was kept for an hour and optical density was noted at $750 \mathrm{~nm}$ against blank with UV spectrophotometer. The blank was prepared with distilled water instead of the extract. The total phenols were calculated by the standard curve drawn with graded concentration of Gallic acid and expressed as $\mathrm{mg}$ of phenols per $100 \mathrm{~g}$ of fruit. The statistical analysis of the data was done by the method described by Panse and Sukhatme (1978) using C.R.D experiment and individual treatment was replicated thrice.

\section{Results and Discussion}

In the study, the data present in Table 1 revealed that the total soluble solids content of candy increased with the increase in duration of storage irrespective of treatments. No significant changes was observed in TSS content during storage. An increase in TSS content may possibly be due to hydrolysis of polysaccharides and oligosaccharides into monosaccharide (reducing sugars) and evaporation of moisture during storage. Among the treatments ginger extract treatment was found to contain minimum changes in TSS content 72.00-73.10 ${ }^{0}$ Brix followed by mentha oil, lemon oil and peppermint oil throughout the storage period. An increase in TSS content during storage was also observed in aonla candy (Pathak, 1988) and (Bhagwandeen, 1992), ber candy (Kumar et al., 1992) and sapota candy (Divya et al., 2012).

Results pertaining to change in acidity (Table2) revealed that acidity significantly increased from second month in all treatments during storage. Pectic substances have been reported to increase the acidity in fruit product. Hence pectic substances might have hydrolyzed and yielded acids that contributed towards an increase in acidity of the products. The maximum acidity was recorded 0.54 per cent in lemon oil followed by ginger during entire storage period. This increase in acidity during storage period was also reported in aonla candy (Pathak, 1988), papaya candy (Kumar, 1990), ber candy (Kumar et al., 1992), aonla candy (Mishra, 2005) and highest acidity recorded in honey coated aonla candy cv. Kanchan followed by NA-6 (Vikram et al., 2014).

Results pertaining to change in ascorbic acid (Table-3) during storage revealed that ascorbic acid content of product significantly declined continuously with the progress of storage period in each treatment up to six months. Reduction in ascorbic acid content may be attributed to oxidation with trapped oxygen in packaging container which results formation of dehydroascorbic acid (Kumar, 1990). Lemon oil treatment retained and maintained maximum ascorbic acid content throughout the entire storage period followed by ginger extract treatment. This decrease in ascorbic acid was in conformity with the findings of aonla candy (Pathak, 1988.; Tripathi et al., 1988; Singh et al., 1993), osmo-dehydrated guava slices (Ayub et al., 1995), intermediate moisture guava slices (Harsimrat and Dhawan, 2002), bael candy (Mishra et al., 2013), high ascorbic acid contain was found in aonla candy cv. NA-7 (Pawar and Patil, 2013) and honey coated aonla candy (Vikram et al., 2014).

A perusal of data in Table 4 depicted a significant increase in reducing sugars so far storage is concerned. This might be due to the inversion of non reducing sugar to reducing sugars and hydrolysis of polysaccharides into monosaccharides. Among all treatments maximum reducing sugars were found in 
lemon oil treatment followed by ginger extract treatment throughout the storage period. It may possibly be due to high inversion of non reducing sugar to reducing sugars because of high content of organic acid (citric acid). An increase in reducing sugars during storage was also found in pineapple candy (Castro et al., 1995), guava leather (Gehlat et al., 2007), aonla candy (Singh et al., 2007) in sapota candy (Divya et al., 2012) and maximum in aonla nectar during 90 days of storage (Choudhary et al., 2012).

The results of the present studies indicated that non reducing sugar continuously decreased (Table-5) up to six months in all treatments till the end of experiment. It may be attributed to inversion of non reducing sugar to reducing sugars. The maximum inversion was seen in ginger extract treatment. A decrease in non reducing sugar during storage is also reported in guava RTS and nectar (Chaudhary and Dikshit, 2006), in aonla preserve (Geetha et al., 2008) in aonla RTS (Lther et al., 2009) and partial decrease in osmo air dried aonla segment were packed in polyethylene terephthalate jar during 6 month of storage (Sumitha et al., 2015).

Results of the present studies revealed that total sugars content increased continuously in all treatments along with the progress in storage period of six months (Table-6). An increase in the total sugars might be due to hydrolysis of polysaccharides like pectin, starch etc. into simple sugars as well as evaporation of moisture during storage. The maximum total sugars content was found in lemon oil treatment $64.20 \%$ followed by ginger extract $63.60 \%$.

These results are in agreement with the findings of guava slices (Harsimrat and Dhawan, 2002), cheese and toffee prepared from bael-guava blends (Gehlot et al., 2007), in aonla pineapple blended RTS (Kumar et al., 2009) in aonla candy (Pawar and Patil, 2013), and in aonla preserve during 90 days of storage (Priya and Khatkar, 2013).

Data presented in (Table-7) non enzymatic browning increased continuously in all treatments up to six months of storage period. This could be mainly due to non enzymatic reaction (maillard reaction) such as organic acids reaction with sugars and amino acids which leads to the formation of brown pigments. Millard (1992) was first describing the development of brown colour in mixture containing amino acid and reducing sugar. Among different treatments ginger extract treatment was found to maintain least browning throughout the entire period of storage. Sulphites not only act as a reducing agent but also have ability to directly inhibit polyphenol oxidase.

The inhibit conversion of D-glucose to Shydroxymethyl-furfural, as well as the conversion of ascorbic acid to furfural by complexing the reducing group. Consequently the formation of furfural is blocked thus preventing the production of colour pigments. Similar result was observed in aonla candy (Pathak 1988), kinnow + aonla + ginger RTS (Bhardwaj and Mukherjee, 2011) in aonla preserve (Priya and Khatkar, 2013), in bael candy (Mishra et al., 2013), and recorded highest in aonla candy cv. Kanchan followed by NA-6, NA-7 and Krishna (Vikram et al., 2014).

The result of the present studies revealed that total phenols content decrease continuously throughout the storage period of six months (Table-8). Since phenolic compounds play an important role in determining the colour and flavor of a product, but its loss might be due to these compounds are highly volatile and easily oxidizable which condensed into brown pigments. Among all treatments peppermint oil treatment was found best continuously 
which contain maximum total phenols content throughout the storage period. These findings are in close conformity with the results obtained by in apple slices treated with $2 \%$ ascorbic acid (Gil et al., 1998), cheese and toffee (Gehlot et al., 2007) prepared from bael-guava blends with progress in storage period.

Table.1 Effect of different natural oil/extract on changes in total soluble solids content (\%) of aonla candy during storage

\begin{tabular}{|c|c|c|c|c|c|}
\hline \multirow{2}{*}{$\begin{array}{l}\text { Storage } \\
\text { period } \\
\text { (Month) }\end{array}$} & \multicolumn{5}{|c|}{ Treatments } \\
\hline & $\begin{array}{l}\text { Ginger } \\
\text { extract }\end{array}$ & Mentha oil & Peppermint oil & Lemon oil & Average \\
\hline $\mathbf{0}$ & 72.00 & 71.00 & 70.00 & 72.00 & 71.25 \\
\hline 1 & 72.15 & 71.10 & 70.20 & 72.25 & 71.43 \\
\hline 2 & 72.35 & 71.26 & 70.35 & 72.55 & 71.63 \\
\hline 3 & 72.57 & 71.47 & 70.45 & 72.77 & 71.82 \\
\hline 4 & 72.75 & 71.68 & 70.60 & 72.95 & 72.00 \\
\hline 5 & 72.90 & 71.95 & 70.78 & 73.35 & 72.25 \\
\hline 6 & 73.10 & 72.15 & 72.00 & 73.64 & 72.72 \\
\hline Average & 72.55 & 71.52 & 70.63 & 72.79 & 71.87 \\
\hline \multicolumn{6}{|c|}{ SEm $\pm \quad$ CD at $5 \%$} \\
\hline \multicolumn{2}{|c|}{ Treatment $(\mathbf{P})$} & 0.41 & 1.17 & & \\
\hline \multicolumn{2}{|c|}{ Storage period $(\mathbf{T})$} & 0.54 & NS & & \\
\hline Interaction & $\times \mathbf{T}$ & 1.09 & & & \\
\hline
\end{tabular}

Table.2 Effect of different natural oil/extract on changes in acidity content (\%) of aonla candy during storage

\begin{tabular}{|c|c|c|c|c|c|}
\hline \multirow{2}{*}{$\begin{array}{l}\text { Storage } \\
\text { period } \\
\text { (Month) }\end{array}$} & \multicolumn{5}{|c|}{ Treatments } \\
\hline & $\begin{array}{c}\text { Ginger extract } \\
(15.00 \mathrm{ml})\end{array}$ & $\begin{array}{l}\text { Mentha oil } \\
(1.0 \mathrm{ml})\end{array}$ & $\begin{array}{c}\text { Peppermint oil } \\
\text { (1.0 ml) }\end{array}$ & $\begin{array}{l}\text { Lemon oil } \\
(1.0 \mathrm{ml})\end{array}$ & Average \\
\hline $\mathbf{0}$ & 0.50 & 0.49 & 0.48 & 0.51 & 0.50 \\
\hline 1 & 0.51 & 0.50 & 0.48 & 0.52 & 0.50 \\
\hline 2 & 0.52 & 0.51 & 0.49 & 0.53 & 0.51 \\
\hline 3 & 0.52 & 0.51 & 0.50 & 0.54 & 0.52 \\
\hline 4 & 0.53 & 0.52 & 0.50 & 0.55 & 0.53 \\
\hline 5 & 0.54 & 0.53 & 0.51 & 0.55 & 0.53 \\
\hline 6 & 0.54 & 0.54 & 0.52 & 0.56 & 0.54 \\
\hline Average & 0.52 & 0.51 & 0.50 & 0.54 & 0.52 \\
\hline \multicolumn{6}{|c|}{ SEm $\pm \quad$ CD at 5\% } \\
\hline & 0.003 & \multicolumn{3}{|l|}{$\begin{array}{l}0.009 \\
0.012\end{array}$} \\
\hline & & 0.004 & \multicolumn{3}{|l|}{0.012} \\
\hline Interaction & Storage period $(\mathbf{P})$ & 0.008 & \multicolumn{3}{|l|}{ NS } \\
\hline
\end{tabular}


Table.3 Effect of different natural oil/extract on changes in ascorbic acid content $(\mathrm{mg} / 100 \mathrm{~g})$ of aonla candy during storage

\begin{tabular}{|c|c|c|c|c|c|}
\hline \multirow{2}{*}{$\begin{array}{c}\text { Storage } \\
\text { period } \\
\text { (Month) }\end{array}$} & \multicolumn{5}{|c|}{ Treatments } \\
\hline & $\begin{array}{c}\text { Ginger extract } \\
(15.00 \mathrm{ml})\end{array}$ & $\begin{array}{l}\text { Mentha oil } \\
(1.0 \mathrm{ml})\end{array}$ & $\begin{array}{c}\text { Peppermint oil } \\
(1.0 \mathrm{ml})\end{array}$ & $\begin{array}{l}\text { Lemon oil } \\
(1.0 \mathrm{ml})\end{array}$ & Average \\
\hline $\mathbf{0}$ & 103.92 & 102.80 & 102.70 & 101.00 & 102.61 \\
\hline 1 & 97.40 & 96.72 & 95.67 & 94.50 & 96.07 \\
\hline 2 & 91.35 & 89.60 & 88.40 & 88.35 & 89.43 \\
\hline 3 & 84.78 & 83.08 & 81.25 & 82.55 & 82.92 \\
\hline 4 & 78.25 & 76.72 & 74.57 & 75.20 & 76.19 \\
\hline 5 & 72.20 & 69.20 & 66.84 & 68.48 & 69.18 \\
\hline 6 & 64.50 & 62.68 & 58.35 & 62.70 & 62.06 \\
\hline Average & 84.63 & 82.97 & 81.11 & 81.83 & 82.63 \\
\hline \multicolumn{6}{|c|}{ SEm $\pm \quad$ CD at $5 \%$} \\
\hline \multicolumn{2}{|c|}{ Treatment (P) } & 0.46 & \multicolumn{3}{|l|}{1.30} \\
\hline \multicolumn{2}{|c|}{ Storage period $(\mathbf{T})$} & 0.61 & \multicolumn{3}{|l|}{1.73} \\
\hline Interaction & $\times T$ & 1.22 & \multicolumn{3}{|l|}{ NS } \\
\hline
\end{tabular}

Table.4 Effect of different natural oil/extract on changes in reducing sugars content (\%) of aonla candy during storage

\begin{tabular}{|c|c|c|c|c|c|}
\hline \multirow{2}{*}{$\begin{array}{l}\text { Storage } \\
\text { period } \\
\text { (Month) }\end{array}$} & \multicolumn{5}{|c|}{ Treatments } \\
\hline & $\begin{array}{l}\text { Ginger extract } \\
(15.00 \mathrm{ml})\end{array}$ & $\begin{array}{l}\text { Mentha oil } \\
\text { (1.0 ml) }\end{array}$ & $\begin{array}{l}\text { Peppermint oil } \\
(1.0 \mathrm{ml})\end{array}$ & $\begin{array}{l}\text { Lemon oil } \\
(1.0 \mathrm{ml})\end{array}$ & Average \\
\hline $\mathbf{0}$ & 35.78 & 35.18 & 34.68 & 35.76 & 35.35 \\
\hline 1 & 36.05 & 35.53 & 34.89 & 36.18 & 35.66 \\
\hline 2 & 36.45 & 36.05 & 35.24 & 36.63 & 36.09 \\
\hline 3 & 36.81 & 36.32 & 35.52 & 37.08 & 36.43 \\
\hline 4 & 37.13 & 36.60 & 35.82 & 37.66 & 36.80 \\
\hline 5 & 37.48 & 37.09 & 36.22 & 38.18 & 37.24 \\
\hline 6 & 37.90 & 37.55 & 36.66 & 38.90 & 37.75 \\
\hline Average & 36.80 & 36.33 & 35.58 & 37.20 & 36.48 \\
\hline \multicolumn{6}{|c|}{ SEm $\pm \quad$ CD at $5 \%$} \\
\hline \multirow{2}{*}{\multicolumn{2}{|c|}{$\begin{array}{l}\text { Treatment }(\mathbf{P}) \\
\text { Storage period }(\mathrm{T})\end{array}$}} & 0.20 & \\
\hline & & 0.27 & \multicolumn{2}{|l|}{0.78} & \\
\hline Interactioi & $\mathbf{P} \times \mathbf{T}$ & 0.55 & \multicolumn{2}{|l|}{ NS } & \\
\hline
\end{tabular}


Table.5 Effect of different natural oil/extract on changes in non reducing sugar content (\%) of aonla candy during storage

\begin{tabular}{|c|c|c|c|c|c|}
\hline \multirow{2}{*}{$\begin{array}{c}\text { Storage } \\
\text { period } \\
\text { (Month) }\end{array}$} & \multicolumn{5}{|c|}{ Treatments } \\
\hline & $\begin{array}{c}\text { Ginger extract } \\
(15.00 \mathrm{ml})\end{array}$ & $\begin{array}{l}\text { Mentha oil } \\
(1.0 \mathrm{ml})\end{array}$ & $\begin{array}{c}\text { Peppermint oil } \\
(1.0 \mathrm{ml})\end{array}$ & $\begin{array}{l}\text { Lemon oil } \\
(1.0 \mathrm{ml})\end{array}$ & Average \\
\hline $\mathbf{0}$ & 26.80 & 26.54 & 25.86 & 26.77 & 26.49 \\
\hline 1 & 26.55 & 26.27 & 25.69 & 26.52 & 26.26 \\
\hline 2 & 26.33 & 25.90 & 25.52 & 26.32 & 26.02 \\
\hline 3 & 26.13 & 25.78 & 25.41 & 26.10 & 25.86 \\
\hline 4 & 26.02 & 25.68 & 25.31 & 25.86 & 25.72 \\
\hline 5 & 25.89 & 25.46 & 25.08 & 25.67 & 25.53 \\
\hline 6 & 25.70 & 25.23 & 24.97 & 25.30 & 25.30 \\
\hline Average & 26.20 & 25.84 & 25.41 & 26.08 & 25.88 \\
\hline \multicolumn{6}{|c|}{ SEm $\pm \quad$ CD at $5 \%$} \\
\hline \multicolumn{2}{|c|}{ Treatment $(\mathbf{T})$} & 0.15 & \multicolumn{3}{|l|}{0.43} \\
\hline & 0.20 & \multicolumn{3}{|l|}{0.56} \\
\hline \multicolumn{2}{|c|}{$\begin{array}{l}\text { Storage period }(\mathbf{P}) \\
\text { Interaction } \quad T \times P\end{array}$} & 0.40 & \multicolumn{3}{|l|}{ NS } \\
\hline
\end{tabular}

Table.6 Effect of different natural oil/extract on changes in total sugars content (\%) of aonla candy during storage

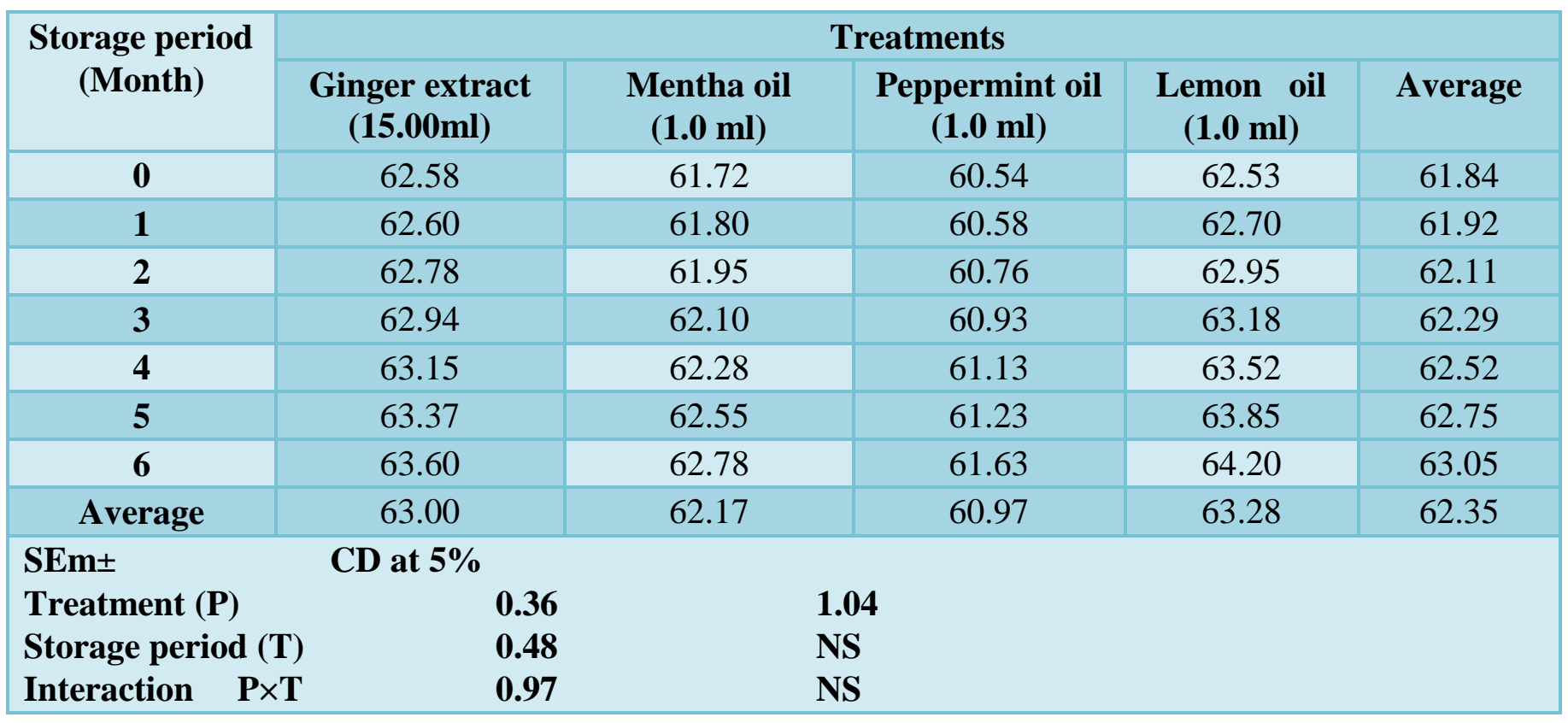


Table.7 Effect of different natural oil/extract on changes in browning (OD) of aonla candy during storage

\begin{tabular}{|c|c|c|c|c|c|}
\hline \multirow{2}{*}{$\begin{array}{l}\text { Storage period } \\
\text { (Month) }\end{array}$} & \multicolumn{5}{|c|}{ Treatments } \\
\hline & $\begin{array}{c}\text { Ginger extract } \\
(15.00 \mathrm{ml})\end{array}$ & $\begin{array}{l}\text { Mentha oil } \\
(1.0 \mathrm{ml})\end{array}$ & $\begin{array}{l}\text { Peppermint oil } \\
\quad(1.0 \mathrm{ml})\end{array}$ & $\begin{array}{l}\text { Lemon oil } \\
(1.0 \mathrm{ml})\end{array}$ & Average \\
\hline $\mathbf{0}$ & 0.04 & 0.06 & 0.05 & 0.05 & 0.05 \\
\hline 1 & 0.05 & 0.07 & 0.06 & 0.06 & 0.06 \\
\hline 2 & 0.06 & 0.08 & 0.08 & 0.08 & 0.08 \\
\hline 3 & 0.08 & 0.10 & 0.09 & 0.10 & 0.09 \\
\hline 4 & 0.09 & 0.11 & 0.11 & 0.11 & 0.11 \\
\hline 5 & 0.10 & 0.12 & 0.12 & 0.11 & 0.11 \\
\hline 6 & 0.11 & 0.13 & 0.12 & 0.12 & 0.12 \\
\hline Average & 0.08 & 0.10 & 0.09 & 0.09 & 0.09 \\
\hline SEm \pm & \multicolumn{5}{|l|}{ CD at $5 \%$} \\
\hline Treatment $(\mathbf{P})$ & \multicolumn{2}{|c|}{0.001} & \multicolumn{3}{|l|}{0.003} \\
\hline \multicolumn{2}{|l|}{ Storage period $(\mathbf{T})$} & & \multicolumn{3}{|l|}{0.003} \\
\hline Interaction $\quad P \times T$ & \multicolumn{2}{|c|}{0.001} & \multicolumn{3}{|l|}{0.003} \\
\hline
\end{tabular}

Table.8 Effect of different natural oil/extract on changes in total phenols content (mg / $100 \mathrm{~g})$ of aonla candy during storage

\begin{tabular}{|c|c|c|c|c|c|}
\hline \multirow{2}{*}{$\begin{array}{l}\text { Storage } \\
\text { period } \\
\text { (Month) }\end{array}$} & \multicolumn{5}{|c|}{ Treatments } \\
\hline & $\begin{array}{c}\text { Ginger extract } \\
(15.00 \mathrm{ml})\end{array}$ & $\begin{array}{l}\text { Mentha oil } \\
(1.0 \mathrm{ml})\end{array}$ & $\begin{array}{l}\text { Peppermint oil } \\
(1.0 \mathrm{ml})\end{array}$ & $\begin{array}{l}\text { Lemon oil } \\
(1.0 \mathrm{ml})\end{array}$ & Average \\
\hline $\mathbf{0}$ & 88.70 & 85.75 & 91.00 & 90.13 & 88.90 \\
\hline 1 & 87.85 & 84.25 & 90.40 & 89.40 & 87.98 \\
\hline 2 & 87.20 & 83.50 & 89.15 & 8825 & 87.03 \\
\hline 3 & 86.57 & 82.25 & 89.85 & 8879 & 86.87 \\
\hline 4 & 85.70 & 81.75 & 88.40 & 87.45 & 85.83 \\
\hline 5 & 84.95 & 80.75 & 87.85 & 87.92 & 85.37 \\
\hline 6 & 84.25 & 79.00 & 87.20 & 86.30 & 84.19 \\
\hline Average & 86.46 & 82.46 & 89.12 & 88.32 & 86.59 \\
\hline \multicolumn{6}{|c|}{ SEm $\pm \quad$ CD at 5\% } \\
\hline \multirow{2}{*}{\multicolumn{2}{|c|}{$\begin{array}{l}\text { Treatment }(\mathrm{T}) \\
\text { Storage period }(\mathrm{P})\end{array}$}} & 0.67 & \multicolumn{3}{|l|}{1.90} \\
\hline & & 0.50 & \multicolumn{3}{|l|}{1.44} \\
\hline Interaction & $T \times P$ & & \multicolumn{3}{|l|}{ NS } \\
\hline
\end{tabular}


Table.9 Effect of different natural oil/extract on physiological weight loss in $(\mathrm{g})$ of aonla candy during storage

\begin{tabular}{|c|c|c|c|c|c|}
\hline \multirow{2}{*}{\begin{tabular}{|c} 
Storage \\
period \\
(Month)
\end{tabular}} & \multicolumn{5}{|c|}{ Treatments } \\
\hline & $\begin{array}{c}\text { Ginger extract } \\
(15.00 \mathrm{ml})\end{array}$ & $\begin{array}{c}\text { Mentha oil } \\
(1.0 \mathrm{ml})\end{array}$ & $\begin{array}{l}\text { Peppermint oil } \\
(1.0 \mathrm{ml})\end{array}$ & $\begin{array}{l}\text { Lemon oil } \\
(1.0 \mathrm{ml})\end{array}$ & Average \\
\hline $\mathbf{0}$ & 200.00 & 200.00 & 200.00 & 200.00 & 200.00 \\
\hline 1 & 199.10 & 198.90 & 198.80 & 198.90 & 198.93 \\
\hline 2 & 197.70 & 197.40 & 197.50 & 197.60 & 197.55 \\
\hline 3 & 196.60 & 196.90 & 195.80 & 196.20 & 196.38 \\
\hline 4 & 195.00 & 194.30 & 194.30 & 195.00 & 194.65 \\
\hline 5 & 193.70 & 192.40 & 193.20 & 193.30 & 193.15 \\
\hline 6 & 191.90 & 189.60 & 191.70 & 190.60 & 190.95 \\
\hline Average & 196.29 & 195.64 & 195.90 & 195.94 & 195.94 \\
\hline \multicolumn{6}{|c|}{ SEm $\pm \quad$ CD at 5\% } \\
\hline \multicolumn{2}{|c|}{ Treatment $(\mathbf{P})$} & 1.09 & \multicolumn{3}{|c|}{ NS } \\
\hline \multicolumn{2}{|c|}{ Storage period $(\mathrm{T})$} & 1.44 & \multicolumn{3}{|l|}{4.10} \\
\hline Interaction & P×T & 2.89 & NS & & \\
\hline
\end{tabular}

Table.10 Effect of different natural oil/extract on changes in organoleptic quality of aonla candy during storage

\begin{tabular}{|c|c|c|c|c|c|c|c|c|c|}
\hline \multirow{3}{*}{$\begin{array}{l}\text { Storage } \\
\text { period } \\
\text { (Month) }\end{array}$} & \multicolumn{8}{|c|}{ Treatments } & \multirow[b]{3}{*}{ Average } \\
\hline & \multicolumn{2}{|c|}{$\begin{array}{c}\text { Ginger extract } \\
(15.00 \mathrm{ml})\end{array}$} & \multicolumn{2}{|c|}{$\begin{array}{l}\text { Mentha oil } \\
(1.0 \mathrm{ml})\end{array}$} & \multicolumn{2}{|c|}{$\begin{array}{l}\text { Peppermint oil } \\
(1.0 \mathrm{ml})\end{array}$} & \multicolumn{2}{|c|}{$\begin{array}{l}\text { Lemon oil } \\
(1.0 \mathrm{ml})\end{array}$} & \\
\hline & Score & Rating & Score & Rating & Score & Rating & Score & Rating & \\
\hline $\mathbf{0}$ & 8.80 & LE & 8.51 & LE & 7.50 & LVM & 7.90 & LVM & 8.18 \\
\hline 1 & 8.75 & LE & 8.35 & LE & 7.37 & LVM & 7.75 & LVM & 8.06 \\
\hline 2 & 8.62 & LE & 8.25 & LE & 7.25 & LVM & 7.62 & LVM & 7.94 \\
\hline 3 & 8.48 & LE & 8.11 & LE & 7.10 & LVM & 7.46 & LVM & 7.80 \\
\hline 4 & 8.35 & LE & 8.00 & LE & 6.95 & LM & 7.30 & LVM & 7.67 \\
\hline 5 & 8.20 & LE & 7.87 & LVM & 6.84 & LM & 7.14 & LVM & 7.54 \\
\hline 6 & 8.00 & LE & 7.75 & LVM & 6.71 & LM & 6.97 & LM & 7.39 \\
\hline Average & 8.46 & & 8.12 & & 7.10 & & 7.45 & & 7.80 \\
\hline \multicolumn{10}{|c|}{ SEm $\pm \quad$ CD at 5\% } \\
\hline \multicolumn{3}{|c|}{ Treatment (P) } & \multicolumn{2}{|c|}{0.04} & \multicolumn{2}{|c|}{0.12} & & & \\
\hline \multicolumn{3}{|c|}{ Storage period $(\mathrm{T})$} & \multicolumn{2}{|c|}{0.05} & \multicolumn{2}{|c|}{0.16} & & & \\
\hline Interactio & P $P \times T$ & & \multicolumn{2}{|c|}{0.11} & \multicolumn{2}{|l|}{ NS } & & & \\
\hline
\end{tabular}


Fig.1 Flow sheet for preparation of flavored aonla candy

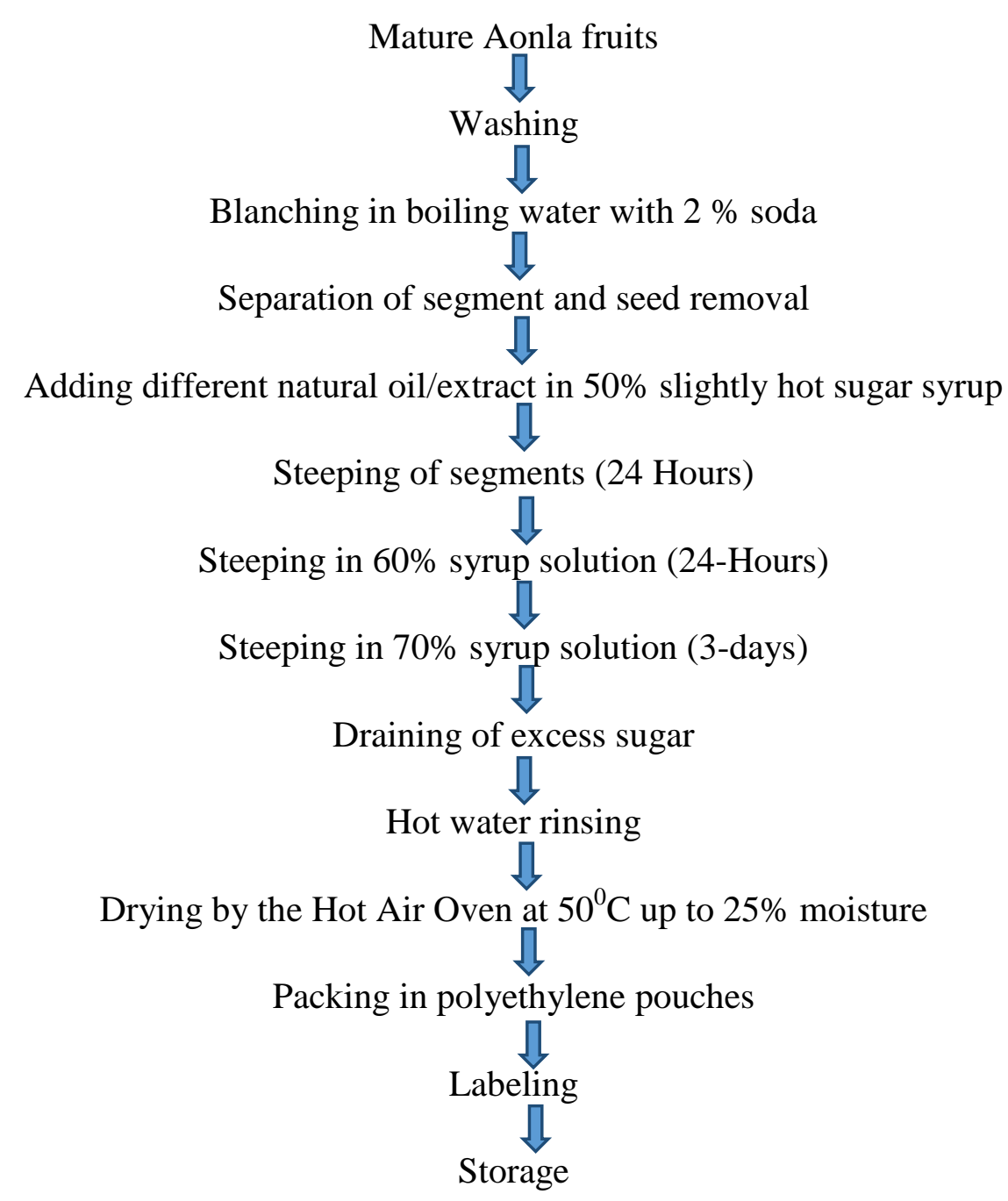

Plate.1.Showing colour difference in aonla candy at zero day in different treatmentsviz-T1, T2, T3, T4, T5, T6, T7, T8, T9 T10 and T11 (Control, Ginger extract, Tulsi oil, Mentha oil, Kewra water, Peppermint oil, Lemon oil, Khus oil, Khus waterRose waterand Eucalyptus oil)

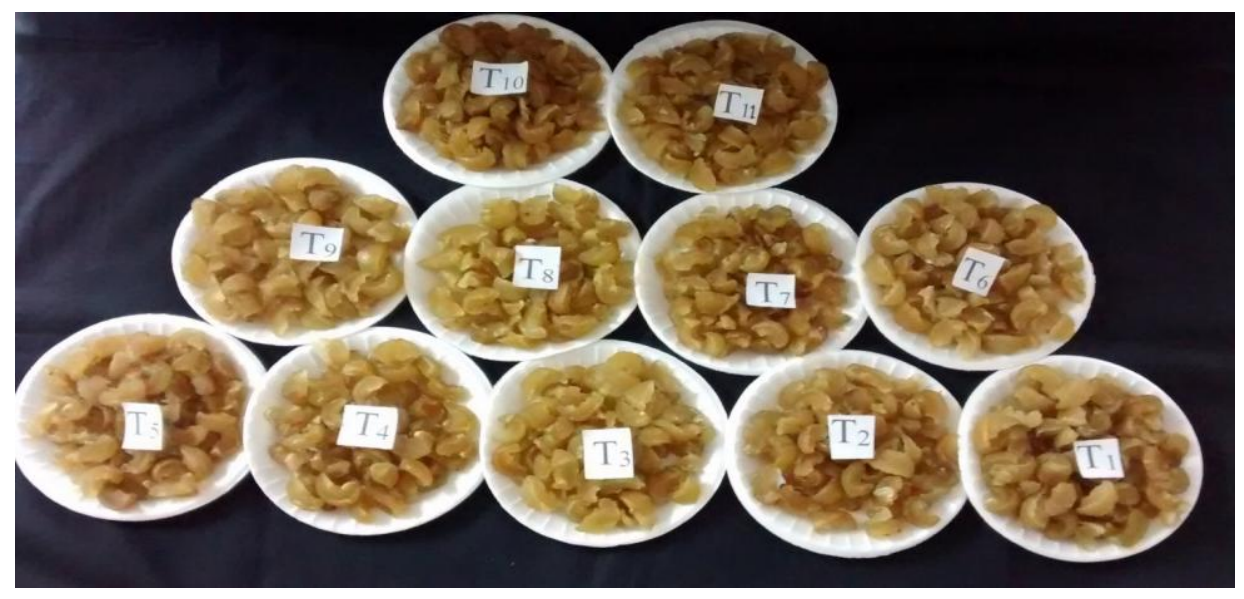


Plate.2 Showing colour difference in aonla candy prepared with ginger extract treatment

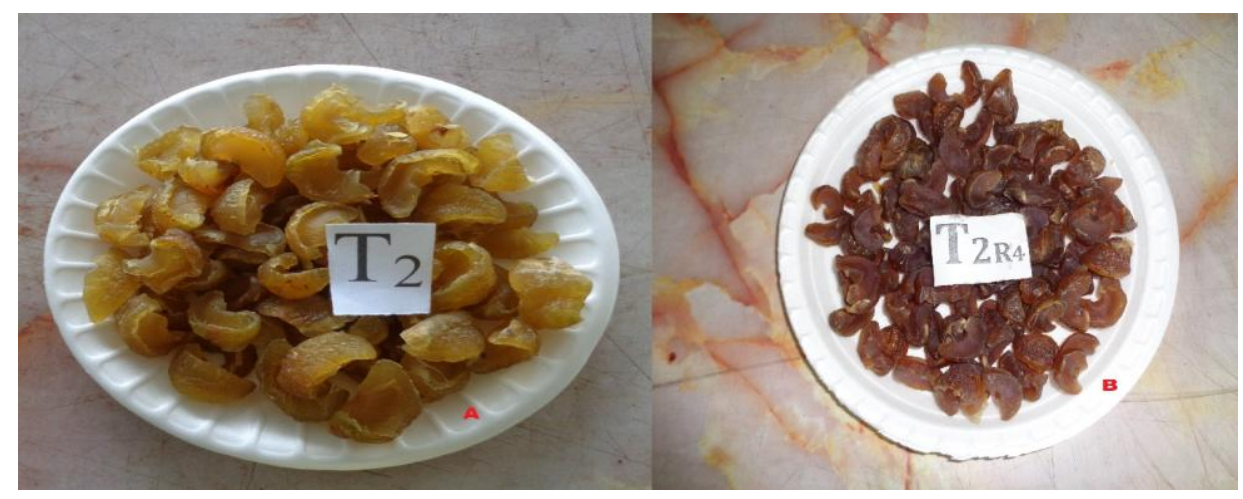

A. At the time of storage

B. After six month of storage.

Plate.3 Showing colour difference in aonla candy prepared with mentha oil treatment

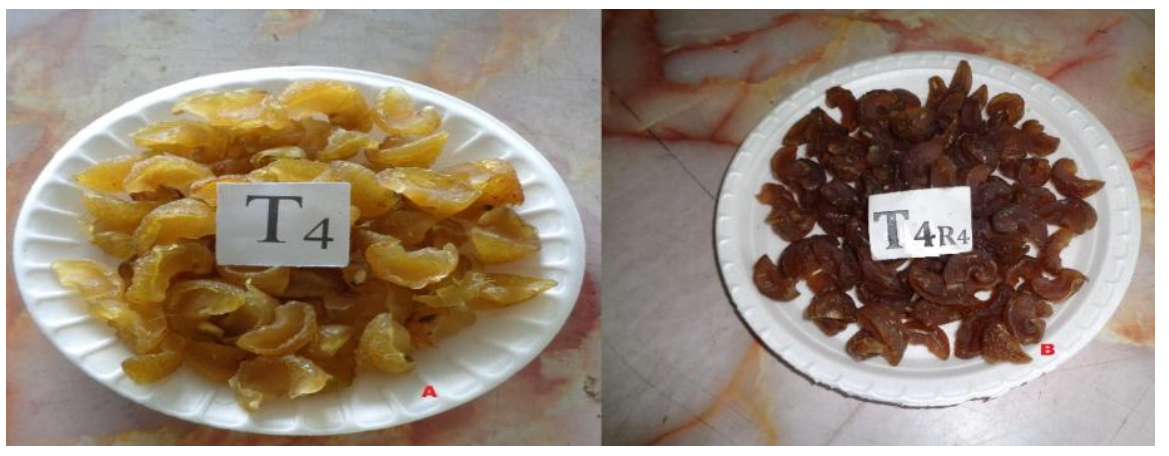

A. At the time of storage

B. After six month of storage.

Plate.4 Showing colour difference in aonla candy prepared with peppermint oil treatment

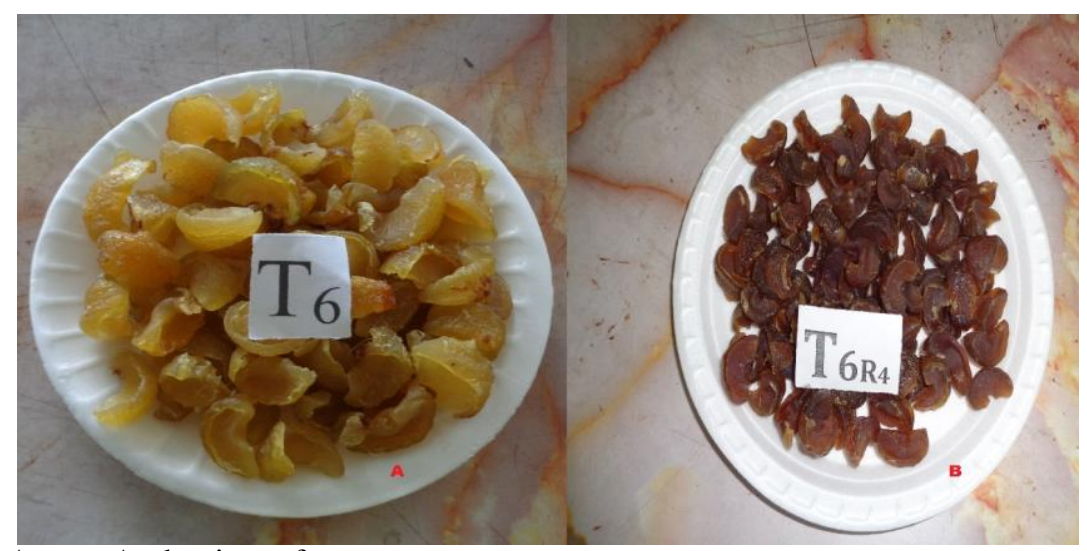

A. At the time of storage

B. After six month of storage 
Plate.5 Showing colour difference in aonla candy prepared with lemon oil treatment

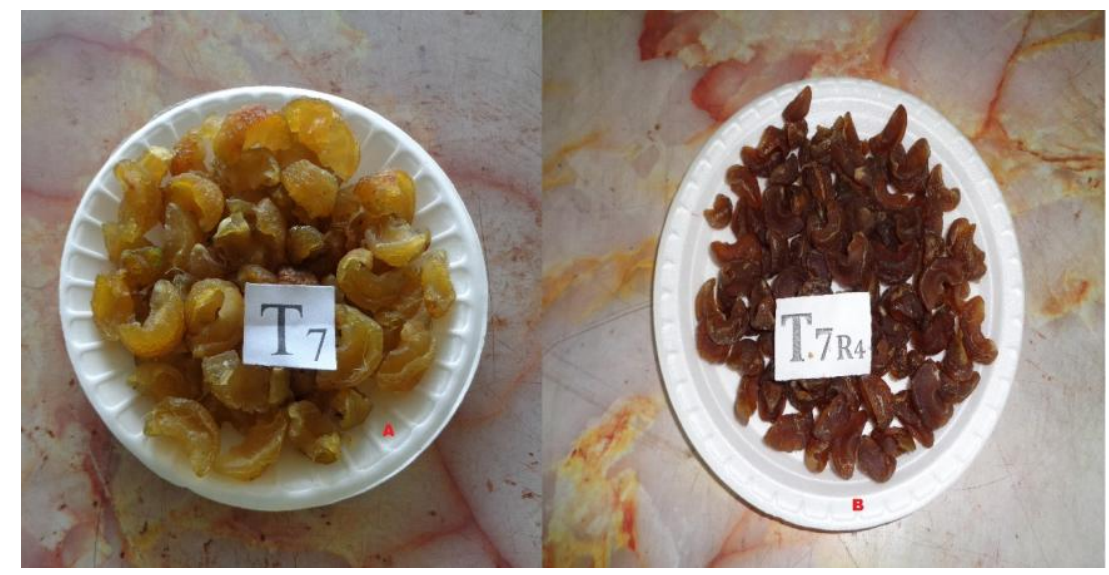

A. At the time of storage

B. After six month of storage

Data represented in Table 9 showed the physiological weight loss of different treatments, days of storage and their interactions. Results of the present studies indicated that physiological loss in weight decreased continuously in all treatments throughout the entire storage period of six months. It may possibly be due to moisture loss in product during storage. Among all treatments ginger extract treatment was found best with least physiological loss in weight maintained throughout the storage period. This observation agrees with the findings of Tripathi et al., (1988) in aonla candy, Mehta et al., (2005) in galgal peel candy and Reshi et al., (2013) in litchi.

Organoleptic score decreased continuously in all treatments up to six months during storage period (Table-10). Candies prepared with all treatments were acceptable up to six months till the end of experiment but ginger extract treatment maintained highest organoleptic score i.e. > 8 (Like very much) throughout the storage period. Sensory quality in terms of colour, flavour and texture of ginger extract treatment was not much altered throughout the storage period in comparison to first day of storage. Candy prepared with mentha oil treatment was also rated like very much up to two months thereafter, it was rated like moderately up to the end of storage because of a little hard texture. Decreasing trend of organoleptic upon prolonged storage of aonla candy has been reported by Singh et al., (1993) and storage life of pineapple candy was judged to be 6 months by Castro et al., (1995).

Results pertaining to cost: benefit ratio (Table-11) revealed that maximum cost: benefit ratio was found with ginger extract treatment $(1: 1.52)$ closely followed by rest of three treatments which contains equal value of cast: benefit ratio (1:1.51). However, on the basis of chemical analysis and organoleptic score ginger extract treatment was found best and can be recommended to processors for commercial production of osmo-dehydrated product (candy) of aonla. Literature pertaining to cost: benefit ratio of aonla candy is lacking.

Based on the present findings it can be concluded that different natural oil/extract treatments influence the quality of candy throughout the storage period. Candy prepared with ginger extract treatment was found best with minimum changes in TSS, and highest sugars content and organoleptic 
quality, less change in acidity and weight, good retention of ascorbic acid and total phenol content, least browning and loss in weight on the basis of chemical analysis and oraganoleptic evaluation. Highest cost: benefit ratio was found in candy treated with ginger extract followed by rest of these three treatments which contains equal value of cost-benefit ratio. However on the basis of chemical composition and organoleptic rating ginger extract treatment was found best, so ginger extract treatment can be recommended for preparation of quality candy of aonla fruit on commercial scale.

\section{References}

Amerine, M.A.; Pangborn, R.M. and Roessler, E.B. Principles of Sensory Evaluation of Food, Academic Press, New York \& London (1965).

A.O.A.C.Official Method of Analysis. Association of official Analytical Chemists, Washington, D.C. $17^{\text {th }}$ edition (1970).

Ayub, M.; Khan, R.; Wahab, S.; Zeb, A.; Muhammad, J. (1995). Effect of crystaline sweeteners on the water activity and shelf stability of osmotically dehydrated guava. Sarhad J. Agri. 11 (6): 755-761.

Bhardwaj, R. L. and Mukherjee, S. (2011). Effects of fruit juice blending ratios on kinnow juice preservation at ambient storage condition. African Journal of Food Science; 5(5): 281-286.

Castro, D.; Vicente, I.; Sevillano, E.; Garcia Arteaga, A.; Torricella, R.; Garcia Roche, M. O. (1995). Candying of pineapple with honey using continuous vacuum technology.2. Study of preservation. Alimentaria, 33: 85-88.

Choudhary, M.L. and Dikshit, S.N. (2006). Studies on shelf life of guava beverages. Current Agri.30 (1/2): 75-78.

Choudhary, M. L.; Verma, I. M.; Singh, J. and Godara, S. L. (2012). Studies on aonla (EmblicaofficinalisGaertn) nectar and biochemical changes with advancement of storage period. Asian Journal of Horticulture; 7(1): 128-132.

Deen, B. (1992). Studies on screening of aonla (Emblica officinalis Gaertn.) genotypes for processing. M.Sc. (Ag.) Thesis, Narendra Deva University of Agriculture \& Technology, Faizabad.

Divya, A. R.; Jayashree, S. and Bhogi, B. (2012). Sensory and nutritional quality of sapota candy. Asian Journal of Home Science; 7(1): 135-139.

Furia, T. E. and Bellanca, N.(1971). Fenaroli's Handbook of Flavor Ingredients. Cleveland, Ohio: Chemical Research Co.

Gil, M. I.; Gorny, J. R. and Kader, A.A. (1998). Responses of 'Fuji' apple slices to ascorbic acid treatments and low-oxygen atmospheres. Hort. Science. 33 (2): 305309.

Gehlot, D. S. and Singh, R. (2007).Studies on physico-chemical composition and changes in bio-chemical constituents of aonla fruits cv. Banarasi during processing into preserve. Haryana Journal of Horticultural Sciences;36(3/4): 247-248.

Geetha, N. S.; Kumar, S. and Rana, G. S. (2008). Effect of osomotic concentration process on sugars and pectin content of aonla preserve during storage at room temperature. Haryana Journal of Horticultural Sciences; 37(3/4): 261-262.

Harsimarat, K. and Dhawan, S.S. (2002). Evaluation of varities for preparation of intermediate moisture guava slice. Crop Research (Hisar), 24 (1): 188-199.

Kumar, S. (1990). Studies on post-harvest Technology of papaya (Carica papaya L.) fruits. Ph.D. theis, N.D. Univ. of Agric. And Tech., Faizabad.

Kumar, P. S. and Sagar, V. R. (2009). Effect of osmosis on chemical parameters and sensory attributes of mango, guava slices and aonla segments. Indian Journal of Horticulture;66(1): 53-57.

Kumar, S.; Ojha, M.; Deen, B.; Awasthi, O.P. and Nainwal, N.C. (1992). Potentiality of ber (Zizyphus mauritiana Lamk) cultivars for candy making. Prog. Hort. 24 $(1 / 2): 74-78$.

Lane, J. H. and Eynon, L. Determination of 
reducing sugars by Fehling Solution with Methylene blue as an indicator. Journal of the Society of Chemical Industry London, 42: 37-7 (1923).

Lather, R.; Sindhu, S. S.; Kumar, J.; Sehrawat, S. K. and Kundu, M. (2009).Studies on the storage behaviour of RTS beverages prepared from aonla juice. Haryana Journal of Horticultural Sciences; 38(3/4): 226-231.

Mehta, A.; Ranote, P.S. and Bawa, A.S. (2005). Processing of kandi lemon (Galgal) peel waste candy making. Indian Food Pack, (1\&2): 67-74.

Mishra, D. K.; Saroj, P.L. and Pathak, S. (2013).Effect of packaging containers on storage stability of bael (Aegle marmelos Correa) candy under ambient conditions. Progressive Horticulture; 45(1): 122125.

Opdyke, D. L. J. (1975). Monographs on Fragrance Raw Materials." Food and Cosmetics Toxicology. 13 (1): 91- 112.

Panse, V.G. and Sukhatme, P.V. (1978). Statistical methods for agricultural workers. I.C.A.R. New Delhi.

Pathak, S. (1988). Post harvest technology of aonla (EmblicaofficinalisGaetrn.) fruits. Ph.D. Thesis N.D. Univ. of Agric. \& Tech., Fiazabad (U.P).

Pawar, M. B. and Patil, D. R. (2013). Sensory attributes changes in aonla (EmblicaofficinalisGaertn) candy during the storage. International Journal of Processing and Post Harvest Technology; 4(2): 118-121.

Priya, M. D. and Khatkar, B. S. (2013). Effect of processing methods on keeping quality of aonla (Emblica officinalis Gaertn.) preserve. International Food Research Journal; 20(2): 617-622.

Rangana, S. (2010). Analysis and quality control

\section{How to cite this article:}

Rajesh Kumar and Sanjay Pathak 2020. Studies on Preparation and Storage of Aonla Candy Enriched with Different Natural Oil/Extract (Emblica officinails L.) cv. NA-7. Int.J.Curr.Microbiol.App.Sci. 9(10): 3285-3299. doi: https://doi.org/10.20546/ijcmas.2020.910.392 for fruit and vegetable products. Tata McGraw Hill Ltd. New Delhi.

Reshi, M., Kaul, R. K., Bhat, A. And Sharma, S. K. 2013. Response OfPost Harvest Treatments On Nutritional Characteristics And Shelf Life Of Litchi (Cv. Dehradun). The bioscan 8(4): 1219-1222.

Swane, T. and Hills, H.E. (1959). The phenolic constituent of Prunus domistica L. Quantitative Analysis of phenolic constituents. J. Sci. Agri. 10: 63-78.

Singh, I.S.; Pathak, R.K.; Dwivedi, R. and Singh, M.K. (1993). Aonla production and post harvest technology. Tech. Bull, Department of Horticulture, Narendra Deva University of Agriculture \&Technology. Faizabad.

Singh, N. Saini, A. and Gupta, A. K. (2007). Nutritional quality of osmotically dehydrated aonla (Emblica officinalis) fruit segments. Indian Journal of Agricultural Biochemistry;20(2): 89-91.

Sumitha, N.; Tiwari, R. B. and Patil, R. A. (2015). Suitability of packaging and storage conditions for osmo-air dried aonla segments Proceedings of the National Academy of Sciences India. Section B, Biological Sciences; 85(1): 203-209.

Tripathi, V.K., Singh, M.B. and Singh, S. (1988). Studies on comparative compositional changes in different preserve products of aonla (Emblica officinalis Gaertn.) Var. Banarasi. Ind. Fd. Pack.., 24 (4): 60-66.

Vikram, B.; Prasad, V. M. and Saroj, P. L. (2014).Comparative study of varieties, honey coating and storage durations on Aonla candy. Indian Journal of Horticulture; 71 (1): 104-108. 